Nalar: Jurnal Peradaban dan Pemikiran Islam

Vol. 2, No. 1, Juli 2018

\title{
Manajemen Komunikasi Badan Amil Zakat Nasional (BAZNAS) Provinsi Jawa Barat
}

\author{
Rama Wijaya Kesuma Wardani \\ Sekolah Tinggi Agama Islam Bumi Silampari Lubuk Linggau, Indoensia \\ aldiscooter7@gmail.com
}

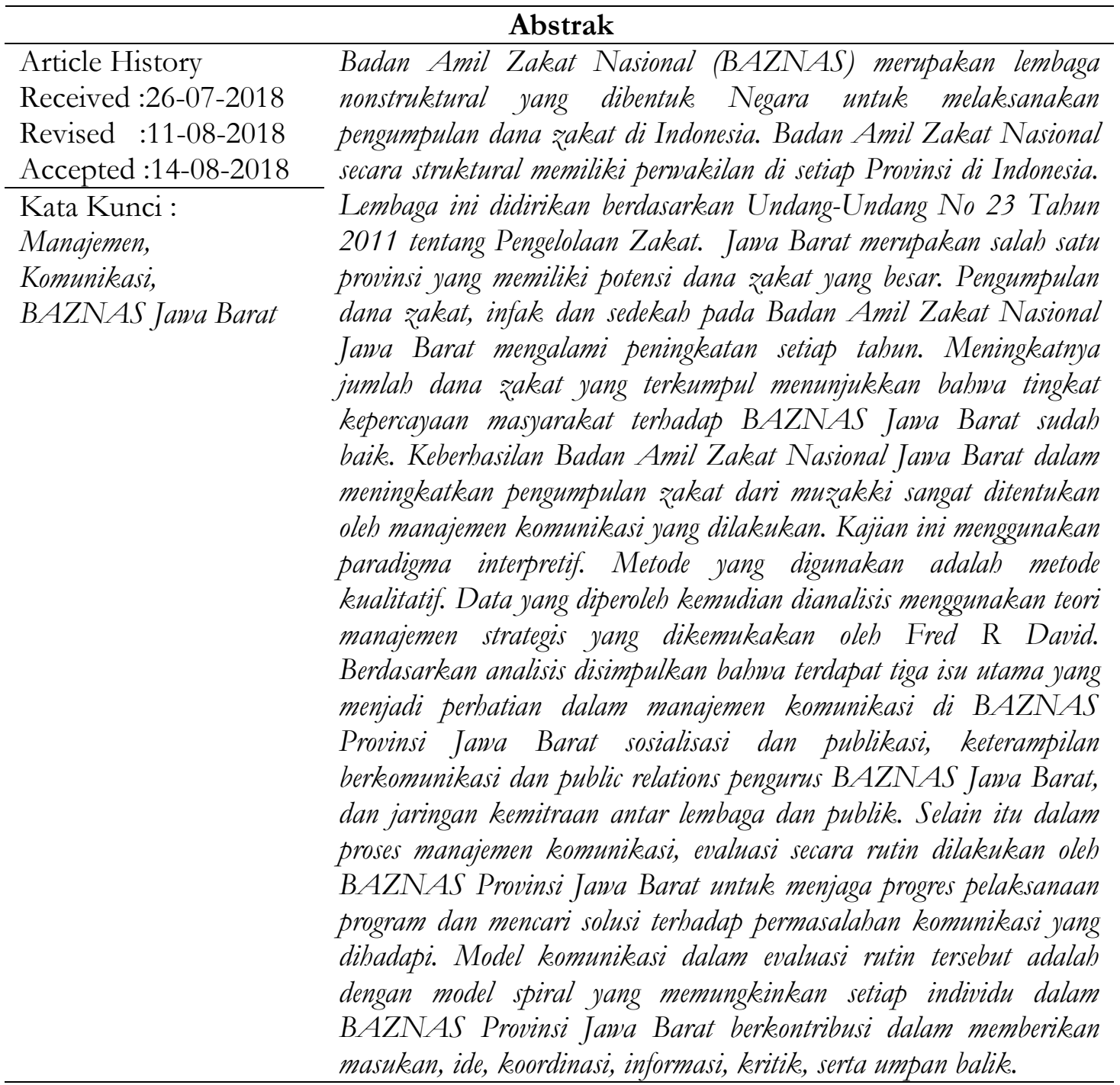

\section{Pendahuluan}

Zakat sebagai salah satu elemen dari rukun Islam tidak hanya memiliki dimensi ibadah namun lebih dari itu, zakat memiliki dampak yang lebih luas terhadap kehidupan sosial dan ekonomi masyarakat. Zakat sebagai salah satu instrumen ibadah terlihat dari sejumlah perintah zakat dalam Al Quran yang selalu disandingkan dengan perintah sholat. Setidaknya, terdapat delapan puluh dua perintah zakat yang selalu dikaitkan dengan perintah sholat. 
Nalar: Jurnal Peradaban dan Pemikiran Islam

Vol. 2, No. 1, Juli 2018

Zakat dalam aspek sosial ekonomi merupakan suatu instrument yang dapat meredistribusikan pendapatan antara yang kaya dengan mereka yang miskin. Dengan ini, maka kesenjangan pendapatan antara kelompok masyarakat kaya dengan masyarakat miskin dapat diminimalisasi. Bagaimanapun, ukuran kaya dan miskin dalam Islam sangat jelas dilihat dari garis nisabnya. Jika kepemilikan seseorang berada di bawah garis nisab maka termasuk dalam kategori miskin (mustabik). Sebaliknya jika berada di atas garis nisab, maka termasuk dalam kelompok non miskin yang berarti wajib menunaikan zakat (muzakk $\imath$ ).

Tataran individu, zakat akan merangsang individu untuk melakukan tabungan akherat dan bermakna pula menggugurkan kewajiban zakat sebagai salah satu rukun Islam yang harus dipenuhi. Selain itu zakat sebagaimana artinya membersihkan menyucikan dan menyuburkan, maka dengan zakat berarti telah memberikan bagian harta si miskin yang ada dalam hartanya. Lebih dari itu, zakat bisa menjadi motivasi bagi individu untuk meningkatkan kinerjanya sehingga selalu termotivasi untuk mengubah dirinya dari mustahik menjadi murakki.

Perintah ambillah zakat dalam hal ini jelas ditujukan kepada Negara untuk mengambil zakat dari masyarakatnya. Hal ini berarti pula bahwa zakat merupakan satu satunya ibadah muamalah yang mempunyai petugas yaitu amil zakat. Cerita sukses zakat dalam upaya mengentaskan kemiskinan dapat kita lihat dari sejarah kejayaan masa pemerintahan Umar Bin Abdul Aziz. Pada masa pemerintahannya tidak lagi ditemukan masyarakat miskin yang berhak menerima zakat sehingga zakat dikirimkan ke negara tetangga yang membutuhkan.

Indonesia pada dasarnya merupakan negara memiliki potensi dana zakat yang cukup tinggi. Hal ini mengingat jumlah umat Islam yang lebih dari 200 Juta jiwa. Hanya saja permasalahan yang muncul adalah pengelolaan dan pengumpulan dana zakat tidak dilakukan secara sistematis dan terstruktur sehingga kemanfaatan dana zakat yang besar tersebut tidak maksimal. Atas dasar inilah kemudian pemerintah menginisiasi lahirnya Badan Amil Zakat Nasional (BAZNAS).

Badan Amil Zakat Nasional (BAZNAS) merupakan lembaga nonstruktural yang dibentuk Negara untuk melaksanakan pengumpulan dana zakat di Indonesia. Badan Amil Zakat Nasional secara struktural memiliki perwakilan di setiap Provinsi di Indonesia. Lembaga ini didirikan berdasarkan Undang-Undang Nomor 23 Tahun 2011 tentang Pengelolaan Zakat. Pembentukan BAZNAS pertama kali ditetapkan dengan Keputusan Presiden No 8 Tahun 2001 tentang Badan Amil Zakat Nasional sesuai amanat UndangUndang No 38 Tahun 1999 tentang Pengelolaan Zakat yang berlaku saat itu. Setelah perubahan regulasi BAZNAS berstatus sebagai lembaga pemerintah nonstruktural yang bersifat mandiri dan bertanggung jawab kepada Presiden melalui Menteri Agama.

Undang-undang Nomor 23 tahun 2011 lahir ditengah rendahnya tingkat kepercayaan masyarakat terhadap lembaga amil zakat. Zaim Zaidi sebagaimana yang dikutip oleh Tempo (2003) menyampaikan bahwa Masyarakat sudah tidak percaya kepada Badan Amil, Zakat, Infaq dan Sadaqah karena tidak adanya transparansi penggunaan dana yang dikelola. Merujuk pada pendapat Zaidi tersebut ketidakpercayaan terhadap lembaga amil zakat disebabkan karena rendahnya keterbukaan lembaga amil zakat terhadap pengelolaan dana zakat, infaq, maupun shadaqah. Selain itu penyaluran dana zakat yang tidak tepat sasaran juga menjadi penyebab rendahnya tingkat kepercayaan masyarakat terhadap lembaga amil zakat. Terkait dengan berbagai penyebab di atas, Romdhon (2014) dalam kajiannya menyebutkan bahwa transparansi memberikan pengaruh yang sangat signifikan terhadap tingkat kepercayaan muzakki. Selain itu Romdhon juga menyebutkan bahwa sikap dan komunikasi yang dilakukan pengelola lembaga amil zakat memainkan peranan yang sangat 
Nalar: Jurnal Peradaban dan Pemikiran Islam

Vol. 2, No. 1, Juli 2018

penting dalam meyakinkan muzakki. Pendapat Romdhon ini juga menunjukkan bahwa penyebab lain ketidakpercayaan masyarakat juga terkait permasalahan komunikasi antara lembaga zakat dengan masyarakat.

Ditengah ketidakpercayaan masyarakat yang begitu tinggi terhadap lembaga Zakat, tetapi justru sebaliknya bagi BAZNAS Jawa Barat. Jawa Barat merupakan salah satu provinsi yang memiliki potensi dana zakat yang besar. Pengumpulan dana zakat, infak dan sedekah pada Badan Amil Zakat Nasional Jawa Barat mengalami peningkatan setiap tahun. Pada tahun 2015, jumlah dana zakat fitrah pada bulan Ramadhan berjumlah Rp. 175 miliar (Rp. 175.961.734.724) dari Tahun 2015. Berdasarkan publikasi Tribun Jabar pada tanggal 17 Oktober 2016, jumlah penerimaan zakat fitrah mengalami kenaikan sebesar Rp. 39 miliar atau sekitar 22 persen pada tahun 2018, di mana pada Ramadhan tahun 2016 zakat fitrah yang terkumpul sebesar Rp. 214 Milliar (Rp. 214.636.56.720). Zakat maal telah terkumpul sebesar Rp. 26 Milliar (26.297.618.326), dan infaq sadakah menyentuh angka Rp. 13 Milliar. Total zakat, infaq dan shadaqah yang terkumpul di bulan Ramadhan berjumlah Rp. 254 miliar (Rp. 253.934.891.439).

Meningkatnya jumlah dana zakat yang terkumpul menunjukkan bahwa tingkat kepercayaan masyarakat terhadap BAZNAS Jawa Barat sudah baik. Hal ini mengingat hingga saat ini di beberapa tempat tingkat kepercayaan masyarakat terhadap pengelolaan dana zakat oleh BAZNAS masih rendah. Realitas tersebut sebagaimana hasil studi yang dilakukan Daulay dan Lubis (2015:250) bahwa tingkat kepercayaan masyarakat terhadap pengelolaan dana zakat masih rendah disebabkan beberapa faktor seperti transparansi pengelolaan dana, sosialisasi yang kurang, dan pelayanan yang diberikan dalam pengumpulan zakat. Hasil studi tersebut menunjukkan bahwa pendekatan dan komunikasi yang dilakukan oleh BAZNAS kepada masyarakat sangat efektif dalam meningkatkan kepercayaan masyarakat.

Strategi komunikasi pada dasarnya sangat berkontribusi terhadap keberhasilan Badan Amil Zakat Nasional Jawa Barat dalam meningkatkan pengumpulan zakat dari muzakeki Pada tataran ini aspek yang memainkan peranan penting adalah perencanaan strategi komunikasi para amil kepada muгakki, baik komunikasi interpersonal, intrapersonal maupun penyampaian isi pesan berkaitan dengan zakat. Dengan demikian komunikasi efektif yang digunakan amil kepada mu₹akki dalam bingkai strategi komunikasi para amil zakat di Badan Amil Zakat Nasional Jawa Barat dapat berpengaruh besar kepada masyarakat terutama para muzakki untuk mengeluarkan zakatnya. Realitas tersebut menjadi menarik untuk diteliti dalam ruang lingkup komunikasi terutama dalam konteks manajemen komunikasi Badan Amil Zakat Nasional Provinsi Jawa Barat dalam mengumpulkan zakat maal.

Pada dasarnya terdapat beberapa kajian terdahulu terkait dengan komunikasi badan amil zakat Nasional. Mishbah El Yaser (2016) misalnya meneliti terkait upaya persuasif BAZNAS Kota Padang dalam menarik minat masyarakat untuk berzakat. Kajian yang dilakukan Yaser pada dasarnya terfokus pada upaya persuasif dan program kerja yang dilakukan oleh BAZNAS dalam menarik minat masyarakat berzakat. Kajian juga dilakukan oleh Rahmi Siti Rahmayati (2013) terkait manajemen pendistribusian dana zakat. Fokus dalam kajian tersebut adalah terkait kebijakan dan manajerial pendistribusian dana zakat kepada mustahiq agar tepat guna dan berkontribusi terhadap pemberdayaan umat. Kajian terkait BAZNAS di atas pada dasarnya lebih terfokus pada pengelolaan dana zakat dan manajemen organisasi. Oleh karena itu kajian terkait manajemen komunikasi lembaga BAZNAS menjadi relevan untuk dilakukan. Kajian tentang manajemen komunikasi diharapkan dapat berkontribusi terhadap khazanah kajian terkait badan amil zakat dan 
Nalar: Jurnal Peradaban dan Pemikiran Islam

Vol. 2, No. 1, Juli 2018

menjadi masukan dalam manajerial lembaga zakat.

Studi yang dilakukan ini menggunakan paradigma interpretif. Metode yang digunakan adalah metode kualitatif. Data dan informasi didapatkan melalui teknik observasi, wawancara, dan dokumentasi. Data yang diperoleh kemudian dianalisis menggunakan teori manajemen strategis yang dikemukakan oleh Freed R. David.

\section{Pengelolaan Zakat di Badan Amil Zakat Nasional (BAZNAS) Jawa Barat}

Badan Amil Zakat Nasional Provisi Jawa Barat merupakan Lembaga formal yang berwenang menghimpun dan mendistribusikan Zakat, Infak, sedekah dan Dana sosial keagamaan lainnya berdasarkan UU no.23 tahun 2011 tentang Pengelolaan Zakat, PP No 14 tahun 2014 tentang pelaksanaan UU no 23 tahun 2011 tentang Pengelolaan Zakat, Keputusan Menteri Agama RI no 186 tahun 2016 tentang Perubahan atas Keputusan Menteri Agama Nomor 118 tahun 2014 tentang pembentukan Badan Amil Zakat Nasional Provinsi, Keputusan Gubernur Jawa Barat Nomor 450.12/ Kep. 919-Yansos/ 2016 tentang perubahan atas keputusan Gubernur Jawa Barat Nomor 450.12/ Kep. 156Yansos/2015 tentang Pimpinan Badan Amil Zakat Nasional (BAZNAS) Provinsi Jawa Barat periode 2014 sampai dengan 2019.

Sebagai sebuah organisasi, sudah sepantasnya memiliki sebuah tujuan yang diharapkan untuk kemajuan yang diinginkan. Tujuan tersebut kemudian dirumuskan dalam visi lembaga. Visi yang diusung BAZNAS Provinsi Jawa Barat adalah "Menjadi Pilihan Utama Muzakki untuk Berzakat di Jawa Barat". Visi tersebut kemudian dijabarkan dalam misi yang menjadi rencana tindakan untuk mewujudkan tercapainya visi lembaga. Adapun misi BAZNAS Provinsi Jawa Barat adalah mempermudah muzakki bertransaksi, mewujudkan desa peradaban zakat, mewujudkan kemandirian masyarakat berbasis potensi lokal, mengayomi organisasi pengolaan zakat di Jawa Barat.

Untuk mewujudkan tercapainya visi lembaga, BAZNAS Provinsi Jawa Barat melaksanakan beberapa program kerja unggulan. Program kerja tersebut diantaranya pembentukan UPZ, gathering muzakki, happening art, open table (kounter layanan ZIS) di pusat keramaian kota, pengadaan kotak infak, infak autodebet via ATM, sosialisasi dan kerjasama dengan berbagai elemen masyarakat. Selain itu BAZNAS Provinsi Jawa Barat juga membangun kemitraan dengan berbagai lembaga dan elemen masyarakat seperti instansi pemerintahan, BUMN, perbankan, perusahaan swasta, yayasan, lembaga pendidikan, perguruan tinggi, dan LSM. Berbagai upaya dalam mewujudkan visi misi lembaga berimplikasi pada peningkatan jumlah dana zakat yang terkumpul di BAZNAS Jawa Barat dari tahun ke tahun. Tahun 2013 dan 2014 jumlah dana zakat yang terkumpul masih berada di bawah 1 milyar rupiah. Namun pada tahun 2015, terjadi peningkatan yang sangat signifikan dalam jumlah dana zakat, infak, dan shadaqah yang berhasil dikumpulkan BAZNAS Provinsi Jawa Barat yaitu lebih dari 20 milyar rupiah.

Meningkatnya penerimaan zakat, infak, dan shadaqah BAZNAS Provinsi Jawa Barat menunjukkan bahwa program kerja yang dilaksanakan mampu meningkatkan kepercayaan dan citra baik lembaga bagi masyarakat. Selain itu program edukasi zakat yang dilakukan juga berhasil memberikan kesadaran terhadap masyarakat terkait manfaat zakat, infak, dan shadaqah bagi kemaslahatan umat. Dana yang terkumpul tersebut kemudian disalurkan dalam berbagai program yang bertujuan meningkatkan perekonomian dan pemberdayaan umat. Secara umum kebijakan umum penyaluran dana zakat disalurkan dalam dua jenis pendayagunaan yaitu bersifat produktif dan santunan.

Kebijakan penyaluran dan pendayagunaan dana zakat, infak, dan shadaqah oleh BAZNAS Provinsi Jawa Barat didasarkan pada skala prioritas dengan memperhatikan 
Nalar: Jurnal Peradaban dan Pemikiran Islam

Vol. 2, No. 1, Juli 2018

prinsip keadilan, pemerataan, dan kewilayahan. Secara keseluruhan ada empat program prioritas dalam penyaluran dan pendayagunaan dana zakat, infak, dan shadaqah di BAZNAS Provinsi Jawa Barat. Pertama, Jabar Cerdas. Program ini terfokus pada bidang pendidikan, seperti beasiswa untuk melanjutkan pendidikan. Kedua, Jabar Mandiri. Program ini terfokus pada bidang ekomoni, seperti pinjaman dengan bagi hasil. Ketiga, Jabar Taqwa. Program ini terfokus pada bidang Dakwah, seperti kegiatan-kegiatan keagamaan, pembangunan masjid. Keempat, Jabar Peduli. Program ini terfokus pada sosial kemanusiaan, seperti, bencana alam dan bencana sosial.

\section{Formulasi Strategi Komunikasi: Mengidentifikasi Sasaran dan Merencanakan Strategi Komunikasi}

Manajemen strategi dalam pandangan David (2012:6) terdiri dari tiga tahap yaitu formulasi, implementasi, dan evaluasi. Aktivitas pada tahap formulasi mencakup persoalan kegiatan mengembangkan visi dan misi organisasi, mengidentifikasi peluang dan ancaman eksternal organisasi, menemukan kekutan dan kelemahan internal organisasi, menetapkan tujuan jangka panjang organisasi, membuat sejumlah strategi alternatif untuk organisasi dan memilih strategi tertentu untuk digunakan. Isu-isu perumusan strategi mencakup keputusan mengenai bisnis baru yang akan dimasuki, bisnis yang akan ditinggalkan, pengalokasian sumber daya, perluasan operasi atau diversifikasi, keputusan untuk memasuki pasar internasional, merger atau membentuk usaha patungan, dan cara untuk menghindari pengambilalihan oleh pesaing bisnis.

Pada tahapan aktivitas formulasi strategi komunikasi, BAZNAS Jawa Barat memfokuskan pada memetakan strategi dalam mengkomunikasikan program dan pengelolaan zakat kepada masyarakat secara tepat. Hal tersebut mengingat Jawa Barat merupakan daerah yang sebagian besar masyarakatnya telah mengenal internet. Selain itu luas wilayah Jawa Barat yang cukup luas menjadi kendala untuk mensosialisasikan program dan pengelolaan zakat dengan bertemu langsung kepada masyarakat. Menyikapi realitas tersebut, dalam tahap proses formulasi BAZNAS Jawa Barat merencanakan penggunaan media sosial dan media massa untuk mensosialisasikan program dan pengelolaan dana zakat yang terkumpul.

Tingginya penggunaan media sosial bukan sesuatu yang aneh di Indonesia. Sejak populer di tahun 2012, ketergantungan masyarakat terhadap media sosial semakin meningkat. Dalam perkembangannya, media sosial pada awalnya hanya digunakan untuk bersosialisasi dengan teman dan kerabat dekat kini mulai menembus komunikasi antara individu dengan institusi. Media sosial juga dewasa ini menjadi jembatan berbagai institusi untuk mensosialisasikan dan mempublikasikan, bahkan melakukan pencitraan di masyarakat. Fungsi media sosial sebagai jembatan untuk sosialisasi dan pencitraan disebutkan Douglas Hagas sebagaimana yang dikutip Ardha (2014: 108) bahwa media sosial bisa berkontribusi besar pada kampanye produk dan politik.

Pesan yang disampaikan di media sosial dan media massa dikonstruk dan di konsep dengan menarik mungkin. Hal ini bertujuan agar masyarakat terpengaruh dan tertarik dengan pesan tersebut. Wilbur Schramm sebagaimana dikutip Marhaeni Fajar (2009:194) mengatakan bahwa terdapat empat syarat untuk berhasilnya pesan. Pertama, pesan harus dirancang dan disampaikan sedemikian rupa, sehingga dapat menarik perhatian sasaran yang dimasud. Kedua, pesan harus menggunakan tanda-tanda yang tertuju pada pengalam yang sama antara sumber dan sasaran, sehingga sama-sama dapat dimengerti. Ketiga, pesan harus membangkitkan kebutuhan pribadi pihak sasaran dan menyarankan beberapa cara untuk memperoleh kebutuhan itu. Keempat, pesan harus menyarankan sesuatu jalan untuk 
Nalar: Jurnal Peradaban dan Pemikiran Islam

Vol. 2, No. 1, Juli 2018

memperoleh kebutuhan yang layak bagi situasi kelompok dimana sasaran berada pada saat ia gerakkan untuk memberikan tanggapan yang dikehendaki.

Efektivitas media sosial dalam sosialisasi lembaga tidak seimbang dengan sumber daya manusia pengelola BAZNAS Provinsi Jawa Barat terkait keterampilan berkomunikasi dan mengelola media sosial dengan baik. Untuk mengatasi hal tersebut BAZNAS Provinsi Jawa Barat mengantisipasinya dengan memberikan berbagai pelatihan untuk meningkatkan keterampilan berkomunikasi terutama terkait public relations. Perhatian yang lebih terhadap keterampilan public relations (PR) disebabkan keterampilan tersebut memiliki peran penting dalam menciptakan dan memelihara hubungan baik lembaga dengan publik/masyarakat. Pada tataran ini Jefkins sebagaimana yang dikutip oleh Rahadini (2010:12) bahwa public relations berkaitan erat dengan nama baik dan reputasi sebuah lembaga. Pendapat Jefkins tersebut sejalan dengan pandangan Hutapea (2000: 31) yang memandang bahwa dalam manajemen komunikasi public relations memiliki fungsi untuk membantu menegakkan dan memelihara aturan bersama dalam komunikasi demi terciptanya kesefahaman dan kerjasama antara lembaga dengan publik/masyarakat. Selain itu public relations juga berperan sebagai alarm tanda bahaya jika terdapat hambatan dan permasalahan komunikasi antara lembaga dengan publik.

Dalam proses formulasi juga ditemukan adanya hambatan berupa jarak komunikasi antara BAZ dengan Masyarakat. Selain itu masih ditemukan masyarakat yang kurang percaya terhadap pengelolaan dana Zakat oleh BAZ sehingga lebih memiliki menyalurkan secara sendiri-sendiri. Mengantisipasi masalah tersebut BAZ dalam tahapan ini merencanakan untuk membangun kemitraan kepada berbagai elemen masyarakat. Kemitraan ini bertujuan agar merangkul masyarakat agar merasa menjadi bagian dari pelaksanaan dan pengelolaan dana Zakat. Secara psikologis ini diharapkan mampu meningkatkan kepercayaan masyarakat.

\section{Implementasi Komunikasi: Realisasi Perencanaan}

Tahap implementasi merupakan upaya merealisasikan perencanaan yang telah dilakukan sebelumnya. Pada tahapan ini komunikasi yang dilakukan bertujuan untuk membangun kepercayaan masyarakat terhadap pengelolaan dana zakat serta membentuk citra positif lembaga. Upaya tersebut secara rutin ditekankan pada transparansi pengelolaan dana zakat dengan mempubikasikan laporan kegiatan Badan Amil Zakat Nasional Provinsi Jawa Barat dimedia massa ataupun media online dan elektronik pada setiap periode kegiatan yang dilakukan oleh Badan Amil Zakat Nasional Provinsi Jawa Barat dan melakukan laporan keuangan baik pendapatan maupun pengeluaran dari muzakki kepada mustahik, maupun kegiatan sosial kemasyarakatan yang bersifat bantuan. Selain itu tahapan komunikasi yang dilakukan juga dengan membangun jaringan organisasi, serta meningkatkan kualitas SDM terkait kemampuan komunikasi.

Secara spesifik terdapat lima aktifitas yang dilakukan BAZNAS Jawa Barat dalam membangun komunikasi dengan masyarakat. Pertama, sosialisasi dan edukasi zakat kepada masyarakat. Sosialisasi zakat dilakukan oleh BAZNAS Jawa Barat dengan menyampaikan dan melakukan pendekatan kepada masyarakat terkait pengumpulan dana zakat. Sosialisasi tersebut dilakukan baik dengan penyampaian informasi secara tatap muka maupun dengan menggunakan media (media massa dan media sosial). Sosialisasi penerimaan zakat kemudian diperkuat dengan melakukan edukasi zakat kepada masyarakat. Tujuan edukasi ini adalah untuk menanamkan kesadaran kepada masyarakat terkait kewajiban dan manfaat zakat bagi kemaslahatan umat. 
Nalar: Jurnal Peradaban dan Pemikiran Islam

Vol. 2, No. 1, Juli 2018

Sosialisasi merupakan bentuk komunikasi untuk menyampaikan sesuatu informasi kepada khalayak secara luas. Program sosialisasi dan edukasi zakat pada dasarnya merujuk Undang-undang No.23/201/2011 tentang Pengelolaan Zakat dan Peraturan Pemerintah (PP) NO.14/2014 tentang Pengelolaan Zakatdan Inpres No 3/2014 tentang Optimalisasi pengumpulan zakat melalui BAZNAS (pusat maupun daerah). Banyak pendekatan yang dapat digunakan dalam sosialisasi. Pada dasarnya bentuk komunikasi yang dilakukan oleh BAZNAS Jawa Barat dalam melaksanakan komunikasi terdiri dari komunikasi tatap muka dan bermedia. Komunikasi tatap muka dipergunakan dengan tujuan untuk mendapatkan efek perubahan tingkah laku (behaviour change) dari komunikan. Hal tersebut dimungkinkan karena dalam berkomunikasi akan terjadi umpan balik langsung. Sedangkan komunikasi bermedia dilakukan sebatas informatif dan tidak memerlukan perubahan tingkah laku secara langsung. Secara keseluruhan komunikasi yang dilakukan oleh BAZNAS Jawa Barat kepada masyarakat untuk sosialisasi dan meningkatkan minat masyarakat untuk berzakat masih dominan menggunakan komunikasi tatap muka. Sementara komunikasi bermedia cenderung digunakan untuk sebatas penyampaian informasi program dan kegiatan yang dilakukan. Hal ini karena pengurus BAZNAS Jawa Barat memandang bahwa komunikasi tatap muka lebih efektif dalam menggugah minat masyarakat untuk berzakat. Pada dasarnya kecenderungan terhadap komunikasi tatap muka relevan dengan pandangan Mulyana (2007:267) bahwa dengan berinteraksi dan bertemu langsung, komunikator bisa mengetahui respon dan tanggapan dari komunikan terhadap pesan yang disampaikan. Selain itu dengan bertemu langsung komunikator dapat membangun hubungan emosional dengan komunikan sehingga mampu mengundang simpati dan keinginan komunikan untuk berzakat.

Kedua, transparansi dan publikasi pengelolaan dana zakat. Transparansi dapat diartikan dengan tindakan menyampaikan informasi secara transparan, konsisten, dan kredibel untuk memberikan layanan yang lebih baik dan lebih cepat kepada pemangku kepentingan. Dalam hal ini transparansi dalam pengelolaan dana zakat oleh BAZNAS Jawa Barat dilakukan dengan menyampaikan informasi secara terbuka kepada masyarakat terkait pengumpulan dan penyaluran dana zakat. Tujuan transparansi ini adalah untuk membangun kepercayaan masyarakat terhadap BAZNAS Jawa Barat. Selain itu transparansi mampu menghilangkan stigma negatif dan kecurigaan masyarakat terhadap lembaga pengelola dana zakat. Untuk mewujudkan transparansi tersebut, BAZNAS secara rutin membuat laporan pertanggungjawaban pengelolaan dana zakat baik secara bulanan, semesteran, maupun tahunan. Kemudian laporan tersebut disampaikan melalui sosialisasi langsung, pengumumam, dan dipublikasi di media sosial.

Transparansi pengelolaan dana zakat oleh BAZNAS Jawa Barat pada dasarnya relevan dengan pendapat George dan Michael (2007:17) yang memandang bahwa transparansi merupakan komponen kognitif dalam menunjang pengumpulan dana zakat. Dalam hal ini transparansi yang dibangun sebuah lembaga dapat meningkatkan tingkat kepercayaan publik terhadap lembaga tersebut. Implikasinya adalah pencapaian tujuan lembaga terhadap minat publik.

Ketiga, membangun kemitraan dan koordinasi dengan seluruh elemen masyarakat. Kemitraan lembaga dibangun BAZNAS Jawa Barat dengan membuat hubungan kerjasama baik melalui MoU maupun integrasi layanan dengan berbagai lembaga lain dan berbagai elemen masyarakat. Melalui interaksi dan komunikasi dalam kemitraan ini dimungkinkan terjadi sinergisitas dan hubungan kerjasama saling menguatkan antar lembaga BAZNAS dengan lembaga lain. Selain itu melalui kemitraan tersebut juga BAZNAS Jawa Barat mengharapkan dukungan masyarakat terhadap layanan dan program yang dibuat. 
Nalar: Jurnal Peradaban dan Pemikiran Islam

Vol. 2, No. 1, Juli 2018

Prasetya (2011:63) memandang bahwa kemitraan selain memperbesar kemungkinan memperoleh kepercayaan dari masyarakat juga sangat efektif dalam membangkitkan masyarakat tentang isu-isu yang diusung oleh suatu lembaga. Pada tataran ini ide, dan pesan yang ingin disampaikan oleh suatu lembaga sangat dimungkinkan untuk mudah diterima oleh lembaga mitra. Pendapat yang dikemukakan Prasetya tersebut pada dasarnya menunjukkan fungsi kemitraan sebagai jembatan penghubung antara BAZNAS dengan masyarakat serta berimplikasi terhadap kepercayaan masyarakat.

Pendapat Prasetya sejalan dengan pandangan Husen Umar (2008:27) yang memandang bahwa kemitraan dapat dilakukan dalam transfer berbagai hal yang dapat diperbantukan sehingga terpadu dalam wujud yang utuh. Pada tataran ini kemitraan dapat juga sebagai penyatuan sejumlah kepentingan yang dapat dikerjakan secara bersama-sama, sehingga memungkinkan akan terjadi hubungan timbal balik antara pihak yang bermitra. Realisasi kemitraan dapat disepakati sebagai sebuah kerjasama yang di dalam operasionalisasinya tidak terdapat hubungan yang bersifat vertikal namun hubungan yang horizontal (setara bagi semua pihak). Pendapat Umar tersebut pada dasarnya menunjukkan bahwa membangun kemitraan akan berimplikasi pada penguatan hubungan dan komunikasi antar lembaga dengan publik. Dengan demikian, memperluas jaringan kemitraan menjadi sebuah keniscayaan untuk dilakukan oleh BAZNAS Jawa Barat.

\section{Evaluasi Komunikasi: Meninjau dan Mengoreksi Proses Komunikasi}

Tahap terakhir manajemen komunikasi yang dilakukan oleh BAZNAS Jawa Barat adalah melakukan evaluasi terhadap seluruh proses komunikasi yang telah dilakukan. Dalam konteks ini evaluasi dilakukan dengan melakukan kilas balik dan mencermati berbagai laporan, serta mereview seluruh tahapan manajemen komunikasi yang telah dilakukan. Hasil dari evaluasi tersebut kemudian menjadi bahan pertimbangan untuk merencanakan kebijakan komunikasi ke depannya.

Temuan di lapangan menunjukkan bahwa evaluasi komunikasi yang dilaksanakan oleh BAZNAS Provinsi Jawa Barat terdiri dari dua jenis. Pertama, evaluasi in-progress. Evaluasi ini dilakukan secara rutin baik secara bulanan maupun semesteran. Evaluasi jenis ini bertujuan untuk memotret sejauhmana progres dan tercapainya realisasi komunikasi pada periode tersebut. Bentuk evaluasi ini biasanya dalam bentuk briefing sebelum melaksanakan agenda rutin, rapat progres bulanan dan semesteran. Kedua, evaluasi pasca kegiatan. Evaluasi jenis ini dilakukan setelah secara keseluruhan proses komunikasi dalam periode waktu yang ditentukan baik yang biasanya dalam periode satu tahunan. Evaluasi jenis ini bertujuan untuk mengukur sejauhmana ketercapaian target BAZNAS Provinsi Jawa Barat yang telah ditentukan awal tahun. Selain itu juga evaluasi jenis ini bertujuan untuk mengevaluasi dan mereview proses komunikasi yang dilakukan dalam seluruh kegiatan pengelolaan zakat.

Evaluasi merupakan suatu keniscayaan dilakukan oleh sebuah lembaga yang berhubungan langsung dengan publik. Pada tataran ini evaluasi dapat berimplikasi terhadap kepuasan dan persepsi publik/masyarakat terhadap BAZNAS Provinsi Jawa Barat. Hal ini sebagaimana pandangan Pace dan Faules (2006:163) yang memandang bahwa kepuasan publik/masyarakat terhadap suatu lembaga merupakan representasi kualitas evaluasi komunikasi internal lembaga yang efektif. Dalam konteks ini evaluasi tidak hanya sekedar mereview berbagai aspek terkait komunikasi yang telah dilakukan, namun juga menjadikan hasil evaluasi sebagai bahan perbaikan untuk meningkatkan performa komunikasi ke depannya. 
Nalar: Jurnal Peradaban dan Pemikiran Islam

Vol. 2, No. 1, Juli 2018

Evaluasi rutin yang dilakukan oleh BAZNAS Provinsi Jawa Barat tidak hanya berimplikasi pada penguatan hubungan dengan masyarakat (eksternal lembaga), tetapi juga terhadap hubungan sesama pengurus BAZNAS (internal lembaga). Evaluasi komunikasi yang dilakukan berperan untuk menemukan permasalahan komunikasi internal lembaga dan kemudian mencari solusi untuk merekatkan kembali hubungan tersebut. Pada tataran ini evaluasi komunikasi berfungsi sebagai upaya pengendalian dan pengkoordinasian semua elemen lembaga. Realitas tersebut sebagaimana yang dikemukakan oleh Katuuk, Mewengkan, dan Kalesaran (2016:9) bahwa evaluasi rutin berfungsi untuk mengkonfirmasi segala aspek terkait komunikasi dan kelancaran operasional suatu lembaga. Untuk memperkuat fungsi evaluasi maka arah komunikasi adalah dengan model spiral (semua arah). Dengan menggunakan model tersebut dimungkinkan setiap unsur dan pengurus BAZNAS Provinsi Jawa Barat dapat berkontribusi dalam memberikan masukan, ide, koordinasi, informasi, kritik, serta umpan balik yang bertujuan untuk meningkatkan kualitas komunikasi internal dan eksternal.

\section{Kesimpulan}

Berdasarkan analisis terhadap temuan data dilapangan, dapat disimpulkan bahwa terdapat tiga isu utama yang menjadi perhatian dalam manajemen komunikasi di BAZNAS Provinsi Jawa Barat. Isu tersebut yaitu sosialisasi dan publikasi, keterampilan berkomunikasi dan public relations pengurus BAZNAS Jawa Barat, dan jaringan kemitraan antar lembaga dan publik. Selain itu dalam proses manajemen komunikasi, evaluasi secara rutin dilakukan oleh BAZNAS Provinsi Jawa Barat untuk menjaga progres pelaksanaan program dan mencari solusi terhadap permasalahan komunikasi yang dihadapi. Model komunikasi dalam evaluasi rutin tersebut adalah dengan model spiral yang memungkinkan setiap individu dalam BAZNAS Provinsi Jawa Barat berkontribusi dalam memberikan masukan, ide, koordinasi, informasi, kritik, serta umpan balik.

Hasil temuan dalam kajian ini menunjukkan bahwa sosialisasi dan pendekatan yang dilakukan BAZNAS Provinsi Jawa Barat belum terlalu memaksimalkan penggunaan media sosial. Oleh karena itu BAZNAS Provinsi Jawa Barat direkomendasikan untuk merancang program atau kebijakan khusus terkait sosialisasi, pendekatan, bahkan pencitraan kepada masyarakat melalui media sosial. Kajian ini memiliki keterbatasan terutapa pada objek kajian yang hanya mengkaji manajemen komunikasi di badan amil zakat di Jawa Barat. Oleh karena itu direkomendasikan untuk kajian selanjutnya adalah terfokus pada perbandingan (komparasi) manajemen komunikasi antara lembaga amil zakat yang berbeda. 
Nalar: Jurnal Peradaban dan Pemikiran Islam

Vol. 2, No. 1, Juli 2018

\section{Daftar Pustaka}

Ardha, Berliani. Social Media sebagai Media Kampanye Partai Politik 2014 di Indonesia. Jurnal Visi Komunikasi Vol. 13 No. 1 tahun 2014.

Daulay, Abdul Hafidz dan Irsyad Lubis. Analisis Faktor Penyebab Keengganan Masyarakat Membayar Zakat melalui BAZIS/LAZ di Kota Medan: Studi Kasus Masyarakat Kecamatan Medan Tambung. Jurnal Ekonomi dan Keuangan Vol. 3 No. 4.

David, Fred R. 2012. Manajemen Strategis: Sebuah Konsep. Jakarta: Salemba Empat.

El Yaser, Mishbah. 2016. Upaya Komunikasi Persuasif Berzakat ke Badan Amil Zakat Nasional di Kota Padang. Skripsi Sarjana Fakultas Ilmu Sosial dan Politik, Universitas Andalas.

Fajar, Marhaeni. 2009. Ilmu Komunikasi: Teori dan Praktek. Yogjakarta: Graha Ilmu.

George, Belch dan George Michael. 2007. Adversiting and Promotion: An Integrated Marketing Communication Perspektive. New York: Mc- Graw Hill.

Hutapea. 2000. Public Relation sebagai Fungsi Manajemen. Majalah Widya Vol. 17 No. 179 tabun 2000.

Katuuk, Oktaviani Margareta, Nourm Mewengkang, dan Edmon R Kalesaran. Peran Komunikasi Organisasi dalam Meningkatkan Eksistensi Sanggar Seni Vox Angelica. Jurnal Acta Diurna Vol. 5 No. 5 tabun 2016.

Mulyana, Dedy. 2010. Imu Komunikasi: Suatu Pengantar. Bandung, Remaja Rosdakarya.

Pace, R Wayne dan Don Faules. 2006. Komunikasi Organisasi: Strategi Meningkatkan Kinerja Perusahaan. Bandung: Remaja Rosdakarya.

Prasetya, Adi Damar. Strategi Komunikasi dalam Penggalangan Dana Lembaga Swadaya Masyarakat Kemitraan. Jurnal Komunikasi dan Realitas Sosial Vol. 2 No. 2 tabun 2011.

Rahadini, MD. Peran Public Relations dalam Membangun Citra Perusahaan melalui Program Corporate Social Responsibility. Jurnal Ekonomi dan Kewirausabaan Vol. 10 No. 1 tabun 2010.

Rahmayati, Rahmi Siti. 2013. Manajemen Pendistribusian Zakat (Studi deskriptif di Rumah Zakat Turangga No 25 C Bandung). Skripsi Sarjana Fakultas Dakwah dan Komunikasi, Universitas Islam Negeri Sunan Gunung Djati Bandung.

Romdhon, Muhammad Rizqi Syahri. 2014. Pengaruh Transparansi Laporan Keuangan, Pengelolaan Zakat, dan Sikap Pengelola terhadap Tingkat Kepercayaan Muzakki. Skripsi Fakultas Pendidikan Ekonomi dan Bisnis, Universitas Pendidikan Bandung.

Umar, Husein. 2008. Strategic Manajemen in Action. Jakarta: Gramedia Pustaka Utama.

Darmawan, Indra. 2003. Tidak Transparan, Badan Amil Zakat Tidak Dipercaya, diakses 12 Juli 2018 dari http://www.tempo.co/read/news/2003/11/01/05526782/TidakTransparaniBadan-Amil-Zakat-Tidak-Dipercaya 